\title{
Climate and environment learning resource guide
}

\section{Laura Bolton}

Institute of Development Studies

January 2021 


\section{About this report}

K4D services are provided by a consortium of leading organisations working in international development, led by the Institute of Development Studies (IDS), with the Education Development Trust, Itad, University of Leeds Nuffield Centre for International Health and Development, Liverpool School of Tropical Medicine (LSTM), University of Birmingham International Development Department (IDD) and the University of Manchester Humanitarian and Conflict Response Institute (HCRI).

This report is based on 12 days of desk-based research.

For any enquiries, please contact helpdesk@k4d.info.

\section{Suggested citation}

Bolton, L. (2021). Climate and environment learning resource guide. Brighton, UK: Institute of Development Studies. DOI: 10.19088/K4D.2021.060

\section{Copyright}

This report was prepared for the UK Government's Foreign, Commonwealth and Development Office (FCDO) and its partners in support of pro-poor programmes. Except where otherwise stated, it is licensed for non-commercial purposes under the terms of the Open Government Licence v3.0. K4D cannot be held responsible for errors or any consequences arising from the use of information contained in this report. Any views and opinions expressed do not necessarily reflect those of FCDO, K4D or any other contributing organisation.

(C) Crown copyright 2021 


\section{Introduction}

This guide is designed to provide information about online resources and materials that can be used to develop or refresh knowledge relevant to FCDO's climate and environment technical competencies. It is not an exhaustive list and further resources may be added. The guide briefly explains what each resource is, what it covers, and an estimate of how long it takes to read/complete (where information is available). The courses and resources are mostly aimed at people with a general level of knowledge about climate and environment.

Particularly useful resources have been highlighted with *Key Report* at the top of the tables in sections 3,4 and 5.

Please note that inclusion in this list does not mean that courses or resources are officially endorsed by FCDO or K4D.

\section{Contents}

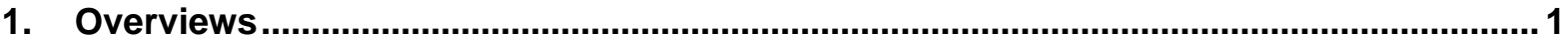

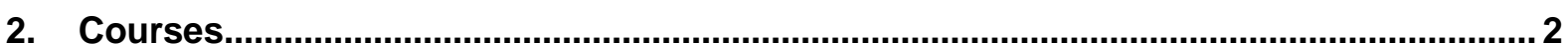

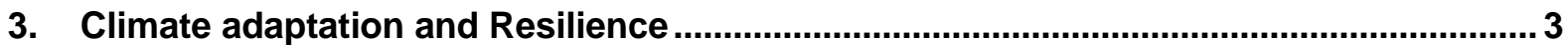

4. Reducing emissions and low-carbon development ...................................................5

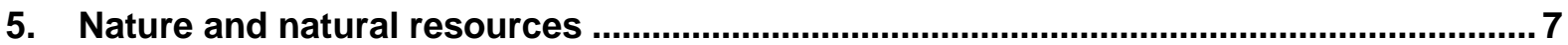

6. Governance - key agreements ................................................................................ 9

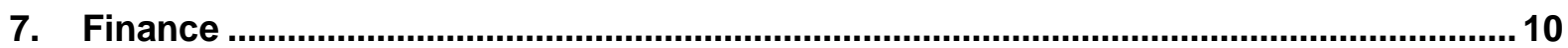




\section{Overviews}

\begin{tabular}{|c|c|c|c|}
\hline Resource & $\begin{array}{l}\text { Document } \\
\text { type }\end{array}$ & $\begin{array}{l}\text { Time / input } \\
\text { required }\end{array}$ & Source type \\
\hline \multicolumn{4}{|l|}{$\begin{array}{l}\text { Theme guides spanning climate and environment from UN } \\
\text { Environment Programme }\end{array}$} \\
\hline $\begin{array}{l}\text { Theme headings link to brief descriptions, further resources and UN work on } \\
\text { a full spectrum of topics including air, biosafety, climate change, ecosystems } \\
\text { and biodiversity, education and environment, energy, environmental rights } \\
\text { governance, extractives, forests, gender, green economy, oceans, resource } \\
\text { efficiency, technology, and water. }\end{array}$ & $\begin{array}{l}\text { Webpage } \\
\text { directory }\end{array}$ & $\begin{array}{l}\text { Varying by the } \\
\text { number of topics }\end{array}$ & $\begin{array}{l}\text { Intergovernmental } \\
\text { body of the UN }\end{array}$ \\
\hline \multicolumn{4}{|l|}{ Broad outline of climate change from the Met Office } \\
\hline $\begin{array}{l}\text { Short description of what climate change is, the evidence that it is occurring, } \\
\text { an outline of the causes and the science behind them, predictions for the } \\
\text { future, impacts of climate change, and what we can do to stop climate } \\
\text { change. }\end{array}$ & Webpage & $\begin{array}{l}\text { Short (up to an } \\
\text { hour) }\end{array}$ & $\begin{array}{l}\text { Executive agency } \\
\text { of the UK } \\
\text { government }\end{array}$ \\
\hline \multicolumn{4}{|l|}{ Article on biodiversity from the World Economic Forum } \\
\hline $\begin{array}{l}\text { Why biodiversity matters to human health, the economy, and to individual } \\
\text { wellbeing. Includes the role of biodiversity in food security, fighting disease, } \\
\text { businesses and livelihoods that depend on nature, and protection from floods. }\end{array}$ & Webpage & $\begin{array}{l}\text { Short (up to an } \\
\text { hour). }\end{array}$ & $\begin{array}{l}\text { International } \\
\text { organisation }\end{array}$ \\
\hline
\end{tabular}




\section{Courses}

\begin{tabular}{lll}
\hline Course & $\begin{array}{l}\text { Time / input } \\
\text { required }\end{array}$ & $\begin{array}{l}\text { Source } \\
\text { type }\end{array}$ \\
\hline $\begin{array}{l}\text { Environmental Studies Course from edX academy } \\
\text { edX is a platform for learning founded by Harvard and MIT. It provides free courses and is } \\
\text { governed by colleges and universities. There are over 150 Environmental Studies Courses } \\
\text { from different high-profile institutions. There is an option to pay for certification. }\end{array}$ & $\begin{array}{l}\text { Range from } 5- \\
100 \text { hours. Self- }\end{array}$ & $\begin{array}{l}\text { Academic } \\
\text { paced. }\end{array}$ \\
$\begin{array}{l}\text { Example - Climate Change Science and Negotiations. This course is estimated to take } \\
\text { between } 20 \text { and } 40 \text { hours. }\end{array}$ &
\end{tabular}

\section{Nature and environment courses from FutureLearn}

Open and interactive learning drawing on the knowledge of the World Bank Group and its partners. Bite-sized lessons to full-length courses. Very large searchable database including archived self-paced learning, webinars and infographics. Some resources require one-off World Bank registration which is free.

Example - Climate change. A 36 part series providing researched knowledge on climate change including videos, games and self-paced e-learning.

\section{Online learning from the World Bank}

Open, interactive learning drawing on the knowledge of the World Bank Group and its partners. Bite-sized lessons to full-length courses. Very large searchable database including archived self-paced learning, webinars and infographics. Some resources require one-off World Bank registration which is free.

Example - Climate change. A 36-part series providing researched knowledge on climate change including videos, games and self-paced e-learning. 


\section{Climate learning from the UN}

UNCC e-Learn is a joint initiative form multilateral organisations providing climate literacy and applied skills development.

Example - Green economy. Introduces basic concepts, policy instruments and international frameworks. Spread over 5 modules, self-paced, 10 hours.

Self-paced course ranging from $2-30$ hours. A number of video tutorials ranging from 20 minutes to 3

hours.

\section{Climate adaptation and Resilience}

\begin{tabular}{|c|c|c|c|}
\hline Resource & $\begin{array}{l}\text { Document } \\
\text { type }\end{array}$ & $\begin{array}{l}\text { Time / } \\
\text { input }\end{array}$ & Source type \\
\hline $\begin{array}{l}\text { *Key Report* The case for climate adaptation from the Global } \\
\text { Commission on Adaption }\end{array}$ & & \multirow{2}{*}{$\begin{array}{l}\text { Executive } \\
\text { summary - } \\
\text { Short. Full } \\
\text { report - } \\
\text { Medium. }\end{array}$} & \\
\hline $\begin{array}{l}\text { Provides specific insights and recommendations in key sectors: food security, the } \\
\text { natural environment, water, cities and urban areas, infrastructure, disaster risk } \\
\text { management, and finance. }\end{array}$ & Report & & $\begin{array}{l}\text { International public } \\
\text { body }\end{array}$ \\
\hline \multicolumn{4}{|l|}{$\begin{array}{l}\text { *Key Report* Report describing the impacts of global warming on } \\
\text { natural and human systems from the Intergovernmental Panel on } \\
\text { Climate Change (IPCC) }\end{array}$} \\
\hline $\begin{array}{l}\text { This chapter in an IPCC special report assesses evidence of climate change impact } \\
\text { focussing on the pattern and magnitude of risk for global warming of } 1.5^{\circ} \mathrm{C} \text { above pre- } \\
\text { industrial period temperatures. It explores observed impacts and projected risks to } \\
\text { different natural and human systems and how risk levels change with rise from } 1.5^{\circ} \mathrm{C} \text { to } \\
2^{\circ} \mathrm{C} \text { of global warming. }\end{array}$ & Report & $\begin{array}{l}\text { Executive } \\
\text { summary } \\
\text { - Short. } \\
\text { Full report } \\
\text { - Medium. }\end{array}$ & $\begin{array}{l}\text { Intergovern- } \\
\text { mental body of } \\
\text { the UN }\end{array}$ \\
\hline
\end{tabular}


The definition of adaptation and resilience from the United Nations Framework Convention on Climate Change (UNFCCC)

This webpage explains what is meant by adaptation and different types of solutions. It lists stakeholders that need to be involved and links to specialised groups and committees working in this area.

\section{A resource on climate change adaptation in vulnerable countries} from the Institute of Environment and Development

This resource describes the common adaptation priorities in 15 African and Asian countries that are highly vulnerable to the impacts of climate change. It outlines strategies that are being used and significant trends.
Short (up

to an

hour).
Intergovernmental body of the UN

\section{Blog on reducing disaster and climate risk in Africa from the World Bank}

Introducing the 'Africa Disaster Risk Management (DRM) Strategic Framework 20162020'. The framework is organised along three main pillars of action: partnerships, knowledge, and investments.

Webpage Short (up to an hour).

Independent research organisation

\section{Two-pager on building resilience in Southeast Asia from the World} Bank

Describes the Japan-World Bank Program Mainstreaming Disaster Risk Management in Developing Countries which supported disaster risk reduction, risk financing, and hydro-meteorological systems.

\section{Article}

Blog $\begin{array}{ll}\text { Short (up } & \text { International } \\ \text { to an } & \text { organisation }\end{array}$

hour). 


Highlighting economic risks associated with climate change impacts
from the London School of Economics $\quad$\begin{tabular}{lc} 
Short (up & Academic \\
$\begin{array}{l}\text { How to understand the nature and magnitude of the risks to lives and livelihoods that } \\
\text { are being created by climate change. Identifies and draws attention to missing and } \\
\text { under-represented risks. }\end{array}$ & $\begin{array}{l}\text { Article an } \\
\text { hour). }\end{array}$ \\
\hline
\end{tabular}

\section{Reducing emissions and low-carbon development}

\begin{tabular}{|c|c|c|c|}
\hline Resource & $\begin{array}{l}\text { Document } \\
\text { type }\end{array}$ & $\begin{array}{l}\text { Time / } \\
\text { input }\end{array}$ & Source type \\
\hline \multicolumn{4}{|l|}{$\begin{array}{l}\text { *Key Report* Special report on mitigation pathway options from the } \\
\text { IPCC }\end{array}$} \\
\hline $\begin{array}{l}\text { This chapter explores mitigation pathways that would limit warming to } 1.5^{\circ} \mathrm{C} \text { above } \\
\text { pre-industrial levels. It looks at the role of } \mathrm{CO}_{2} \text { and non- } \mathrm{CO}_{2} \text { emissions; implications for } \\
\text { transitions in energy, land use and sustainable development; and the ability of policy } \\
\text { frameworks to limit warming. }\end{array}$ & Report & $\begin{array}{l}\text { Executive } \\
\text { summary - } \\
\text { Short. Full } \\
\text { report - } \\
\text { Medium. }\end{array}$ & $\begin{array}{l}\text { International } \\
\text { organisation }\end{array}$ \\
\hline \multicolumn{4}{|l|}{ Introduction to mitigation from the UNFCCC } \\
\hline $\begin{array}{l}\text { Defining mitigation and the responsibilities of Parties to the Framework Convention. } \\
\text { Describes actions by developed countries, such as economy-wide caps, and } \\
\text { developing countries focus on specific programmes and projects. }\end{array}$ & Webpage & $\begin{array}{l}\text { Short (up to } \\
\text { an hour) }\end{array}$ & $\begin{array}{l}\text { International } \\
\text { organisation }\end{array}$ \\
\hline
\end{tabular}




\section{Outlook for World Energy from the International Energy Agency}

Infographics provide an overview of how the global energy system could develop in the Report coming decade. Key uncertainties facing the energy sector are highlighted. The report provides strategic insights based on detailed modelling of different pathways for moving forward.

Overview - Autonomous short. Full report intergovernmental medium.

\section{0 report on emissions gap from the United Environment Programme}

Shows the difference between greenhouse gas predictions and where emissions should be to avoid the worst impacts of climate change. Infographics show key statistics including different scenarios for 2030 and largest causes of emissions.

Key messages 3-pager

\section{Key}

Report messages short. Full report medium.

\section{Report on green growth post-Covid from the Global Green Growth Institute}

Explores challenges and opportunities of the COVID pandemic and how they link with health and climate crises. It looks at the lessons learnt from past disasters on building back better.

\section{Article on natural climate solutions from the Proceedings of the National Academy of Sciences journal}

Looks at the extent to which climate mitigation could be achieved though nature. This includes conservation, restoration, and/or improved land management actions that increase carbon storage and/or avoid greenhouse gas emissions across global forests, wetlands, grasslands, and agricultural lands.
Article

$\begin{array}{ll}\text { Medium (> } & \text { Peer-reviewed } \\ 1 \text { hour, up } & \text { journal } \\ \text { to a day). } & \end{array}$
to a day).
Medium (> Intergovernmental 1 hour, up organisation to a day).
International organisation
Report 


\section{Explainer on the costs of climate mitigation from Our World in Data}

Describes the most common way of measuring and visualising the economic cost of mitigating climate change - abatement cost curves. Data on cost per tonne of carbon Article Short (up to Academic emissions avoided estimates how much it would cost to implement different reduction options.

\section{Summary of how air pollution affects health from the World Health Organization (WHO)}

Outlines major pollution sources and describes the interaction of air quality with climate Webpage and ecosystems. The information includes a list of actions to reduce air pollution and

\section{Nature and natural resources}

\begin{tabular}{|c|c|c|c|}
\hline Resource & $\begin{array}{l}\text { Document } \\
\text { type }\end{array}$ & $\begin{array}{l}\text { Time / } \\
\text { input }\end{array}$ & Source type \\
\hline \multicolumn{4}{|l|}{$\begin{array}{l}\text { *Key Report* Global assessment report on biodiversity and } \\
\text { ecosystem services from the Intergovernmental Science-Policy } \\
\text { Platform on Biodiversity and Ecosystem Services (IPBES) }\end{array}$} \\
\hline $\begin{array}{l}\text { Assesses the status and trends of biodiversity and ecosystem services, the impact of } \\
\text { these on human wellbeing, and the effectiveness of responses. } \\
\text { Summarv for policv makers }\end{array}$ & Report & $\begin{array}{l}\text { Medium (> } \\
1 \text { hour, up } \\
\text { to a day). }\end{array}$ & $\begin{array}{l}\text { Independent } \\
\text { intergovernmental } \\
\text { body }\end{array}$ \\
\hline
\end{tabular}




\section{Feature story on forests from the World Bank}

Describes the valuable role that forests play for people including subsistence and

Webpage

Short (up International income. Discusses the benefits of forests for the planet as part of critical ecosystem services.

to an organisation

\section{Information on nature-based solutions from the WWF}

Outlines nature-based solutions (NBS) for addressing threats to water security, natural Webpage disasters, and climate change. Describes examples and discusses how to assess

hour).

whether NBS are appropriate.

Short (up NGO

to an

hour).

\section{Overview of water and development from the World Bank}

Explains the connections between water and different aspects of development and the Webpage importance of safely managed water, sanitation, and hygiene (WASH) services for

health. The role of water in the economy is also outlined.

Short (up International

to an organisation

hour).

\section{Overview of environmental sustainability and building climate resilience from the International Fund for Agricultural Development (IFAD)}

Highlighting the interplay between agriculture and the environment. Looking at farming practices to help safeguard the environment and sustainable agriculture intensification.

Webpage

Reports
Short (up Intergovernmental

to an hour). body of the UN

\section{Information on the economics of biodiversity from a UK} Government commissioned review

Review assessing the economic benefits of biodiversity globally, assessing the economic costs and risks of biodiversity loss, identifying a range of actions that can simultaneously enhance biodiversity and deliver economic prosperity.

\author{
Medium (> Government \\ 1 hour, up commissioned \\ to a day).
}




\section{Governance - key agreements}

\begin{tabular}{|c|c|c|c|}
\hline Resource & $\begin{array}{l}\text { Document } \\
\text { type }\end{array}$ & $\begin{array}{l}\text { Time / } \\
\text { input }\end{array}$ & Source type \\
\hline \multicolumn{4}{|l|}{ The Paris Agreement } \\
\hline $\begin{array}{l}\text { A legally binding international treaty on climate change adopted in Paris at the end of } \\
2015 \text { and entered into force in November } 2016 \text {. This overview describes the key goal, } \\
\text { how the agreement works, how countries are supporting each other, how progress is } \\
\text { being tracked, and achievements so far. }\end{array}$ & Webpage & $\begin{array}{l}\text { Short (up } \\
\text { to an hour). }\end{array}$ & $\begin{array}{l}\text { Intergovernmental } \\
\text { body of the UN }\end{array}$ \\
\hline \multicolumn{4}{|l|}{ Convention on Biological Diversity } \\
\hline $\begin{array}{l}\text { Information on how the Convention on Biological Diversity promotes nature and human } \\
\text { wellbeing. Describes the call to action, national and international level action, and next } \\
\text { steps. }\end{array}$ & Report & $\begin{array}{l}\text { Medium (> } \\
1 \text { hour, up } \\
\text { to a day). }\end{array}$ & $\begin{array}{l}\text { Intergovernmental } \\
\text { body of the UN }\end{array}$ \\
\hline \multicolumn{4}{|l|}{ United Nations Convention to Combat Desertification } \\
\hline $\begin{array}{l}\text { This webpage provides a brief overview of the convention and links to the convention } \\
\text { text, the strategic framework, ratification and the } 10 \text {-year strategy. }\end{array}$ & Webpage & $\begin{array}{l}\text { Overview } \\
\text { short, } \\
\text { medium to } \\
\text { go in- } \\
\text { depth. }\end{array}$ & $\begin{array}{l}\text { Intergovernmental } \\
\text { body of the UN }\end{array}$ \\
\hline
\end{tabular}




\section{Finance}

\begin{tabular}{|c|c|c|c|}
\hline Resource & $\begin{array}{l}\text { Document } \\
\text { type }\end{array}$ & $\begin{array}{l}\text { Time / } \\
\text { input }\end{array}$ & Source type \\
\hline \multicolumn{4}{|l|}{ Course on climate finance from the World Bank } \\
\hline $\begin{array}{l}\text { Looking at climate finance practices from different development partners to build } \\
\text { capacities in planning, accessing, delivering, and monitoring climate finance at the } \\
\text { national level. }\end{array}$ & Course & 30 hours & $\begin{array}{l}\text { International } \\
\text { organisation }\end{array}$ \\
\hline \multicolumn{4}{|l|}{$\begin{array}{l}\text { Article on the role of financial institutions in addressing nature- } \\
\text { related risks from Global Canopy }\end{array}$} \\
\hline $\begin{array}{l}\text { This article outlines five developments occurring for financial institutions to tackle } \\
\text { nature-related risks: The Taskforce on Nature-related Financial Disclosures; global } \\
\text { policy targets for nature; how financial supervisors and regulators look at nature- } \\
\text { related risks; independent nature-related commitments from financial institutions; and } \\
\text { improved reporting from corporates. }\end{array}$ & Webpage & $\begin{array}{l}\text { Short (Up } \\
\text { to an hour). }\end{array}$ & NGO \\
\hline \multicolumn{4}{|l|}{$\begin{array}{l}\text { The 'Inevitable Policy Response' project from the United Nations } \\
\text { Principle for Responsible Investment }\end{array}$} \\
\hline $\begin{array}{l}\text { Describes the 'Inevitable Policy Response' (IPR) project set up to prepare investors for } \\
\text { the portfolio risks associated with climate change. It is a forecasting tool providing a } \\
\text { realistic outline of the coming policy response in the 2020's and quantifying the } \\
\text { financial risks that it presents. }\end{array}$ & Webpage & $\begin{array}{l}\text { Short (Up } \\
\text { to an hour). }\end{array}$ & $\begin{array}{l}\text { Initiative of an } \\
\text { intergovernmental } \\
\text { body of the UN }\end{array}$ \\
\hline
\end{tabular}

